
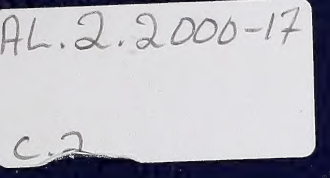



\section{DOWN STREAM CREEL CENSUS OLDMAN RIVER DAM PROVINCIAL RECREATION AREA}

Data Prepared for Environmental Protection Natural Resources by Jeff Wainman

PROJECT DURATION: Jaly 7, 1996 TO August 30, 1996 



\section{TABLE OF CONTENTS}

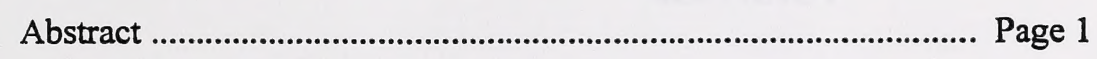

Acknowledgements.................................................................. Page 2

List of figures, tables.................................................................... Page 3

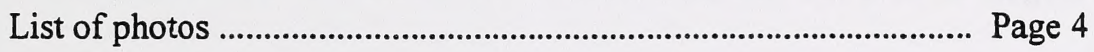

Area Map - Oldman River Dam P.R.A. ...................................... Page 5

Table 1 - Provincial limits.......................................................... Page 6

Introduction, study area.......................................................... Page 7

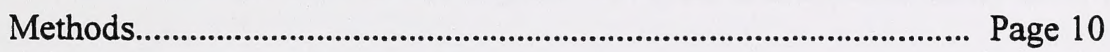

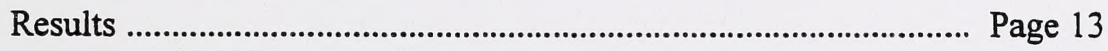

Census statistical forms ........................................................... Page 18

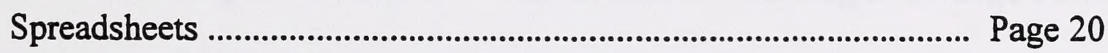

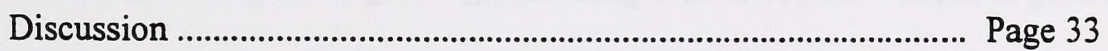





\section{ABSTRACT}

A recreational use demographical creel survey was conducted on the Oldman River, downstream of the Oldman River Dam from July 12, 1996 to August 19, 1996. A total of 254 anglers were surveyed. Alberta residents accounted for $95 \%$ of anglers surveyed of which $74 \%$ were local residents (Albertans residing within $100 \mathrm{~km}$ ), $21 \%$ were non-local residents (Albertans residing farther than $100 \mathrm{~km}$ ) and $5 \%$ were non-provincial. Males accounted for $83 \%$ of the anglers surveyed, and approximately $69 \%$ were licenced sport anglers (16 to 64 years old).

Of 236 rainbow trout (Oncorhynchus mykiss) caught by anglers, 18 were harvested which ranged from $27 \mathrm{~cm}-49 \mathrm{~cm}$ in nose to fork length (average $36.7 \mathrm{~cm}$ ), weighed from $275 \mathrm{~g}-1150 \mathrm{~g}$ (average $574 \mathrm{~g}$ ), and ranged from $15.5 \mathrm{~cm}-25 \mathrm{~cm}$ in girth (average $19.4 \mathrm{~cm}$ ).

A pair of osprey ( Pandion haliaetus) was frequently observed along the stretch of the Oldman River between Cottonwood campground and the Summerview bridge, which is a good barometer of a healthy fishery. 



\section{ACKNOWLEDGMENTS}

The author would like to extend sincere thanks to the following parties involved in providing the opportunity to conduct this study.

The Oldman Monitoring Committee for funding the study and making it possible.

Martin Paetz, Ranger in Charge, Oldman River Dam Provincial Recreation Area, for providing accommodations closely situated to the study area in Cottonwood Campground, and equipment required to conduct the study.

Thanks is also extended to the staff of the Oldman River Dam Provincial Recreation Area and the Oldman Reservoir Office for providing assistance with orientation to the study area, for the use of reference materials and word processing equipment. 
Digitized by the Internet Archive in 2015 


\section{LIST OF FIGURES}

Figure

1. Location of study area

\section{LIST OF TABLES}

\section{Table}

1. 1996 Sportfishing Regulations for the Oldman River within the study area 


\section{LIST OF PHOTOS}

1. WBR access road

2. EBR access road

3. $\mathrm{CBL}$

4. Cottonwood Campground

5. $\mathrm{CDU}$

6. ORP

7. NE shore of Summerview Bridge

8. SE shore of Summerview Bridge

9. NE and SE shore of 6 th Avenue bridge in Fort Macleod

10. NW shore of Monarch bridge 

Photo 1. WRB access road
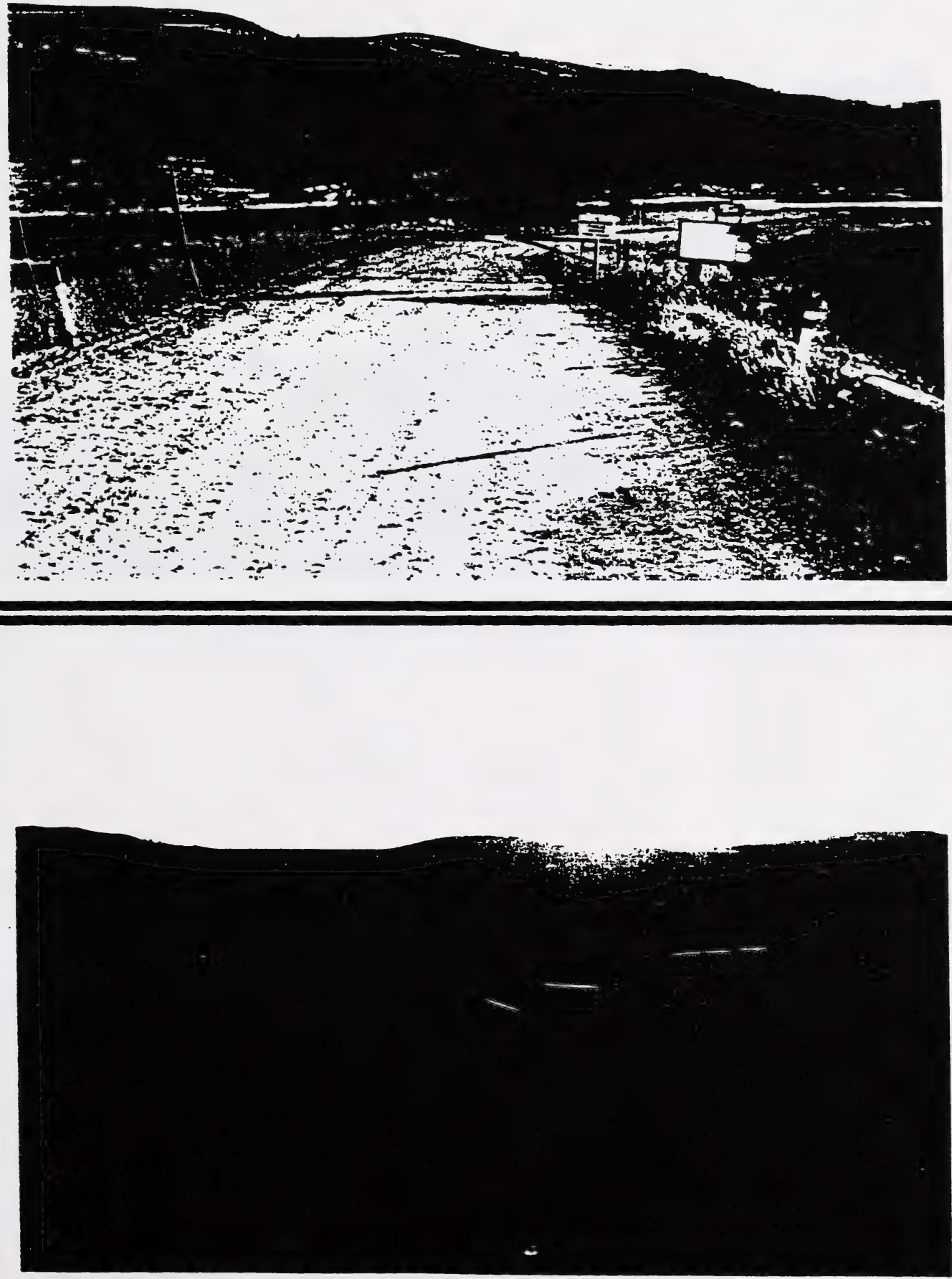

Photo 2. EBR access road 


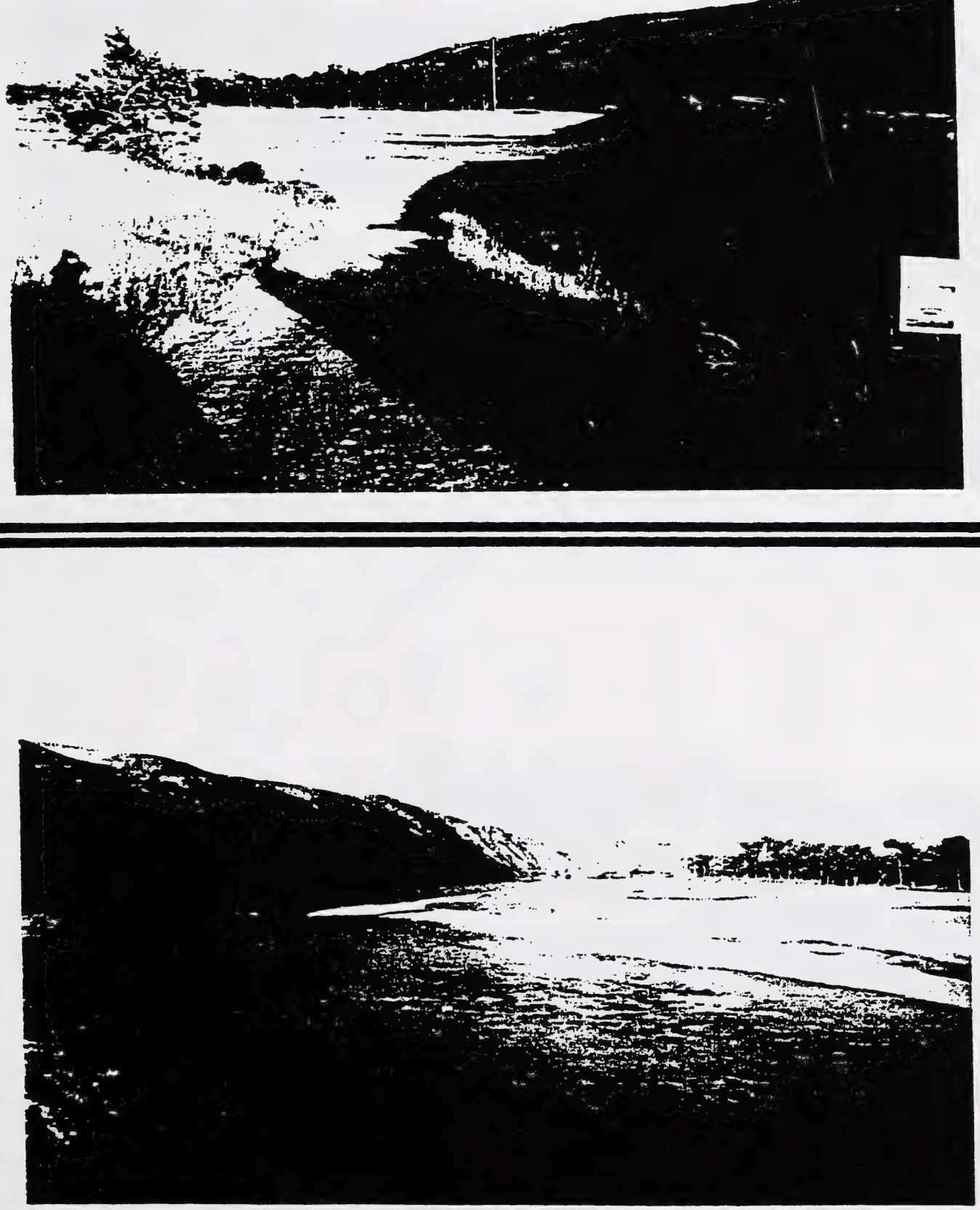

Photo 4. Cottonwood Campground 


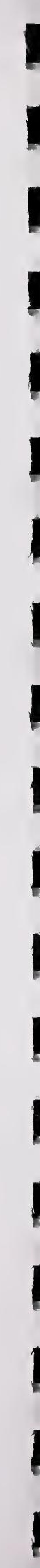


Photo 5. CDIJ
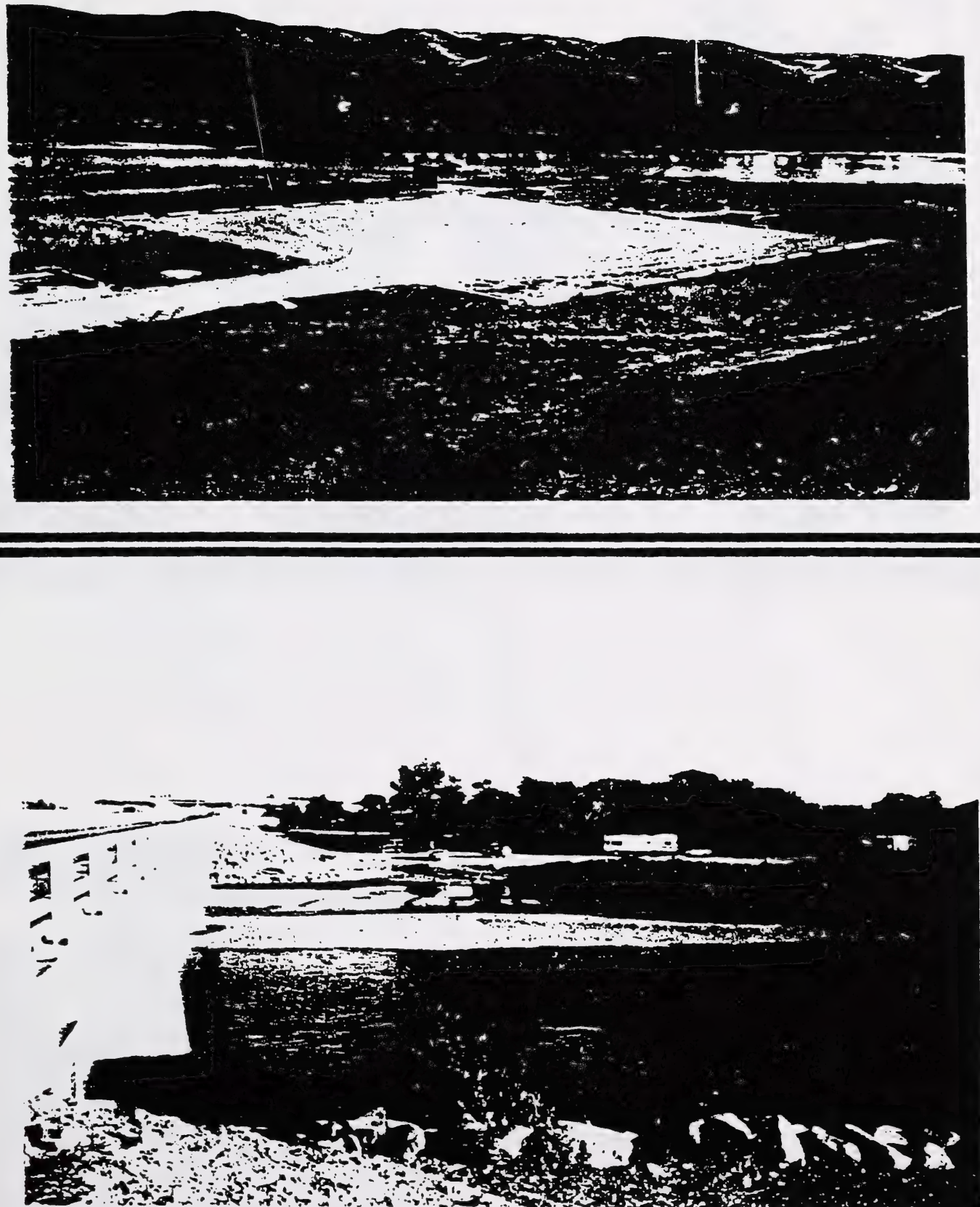

Photo . IR 


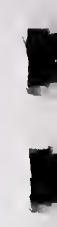

,

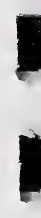

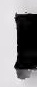

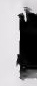

I

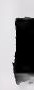

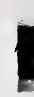

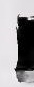

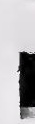

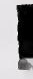

I

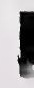

I

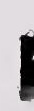

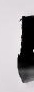

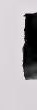



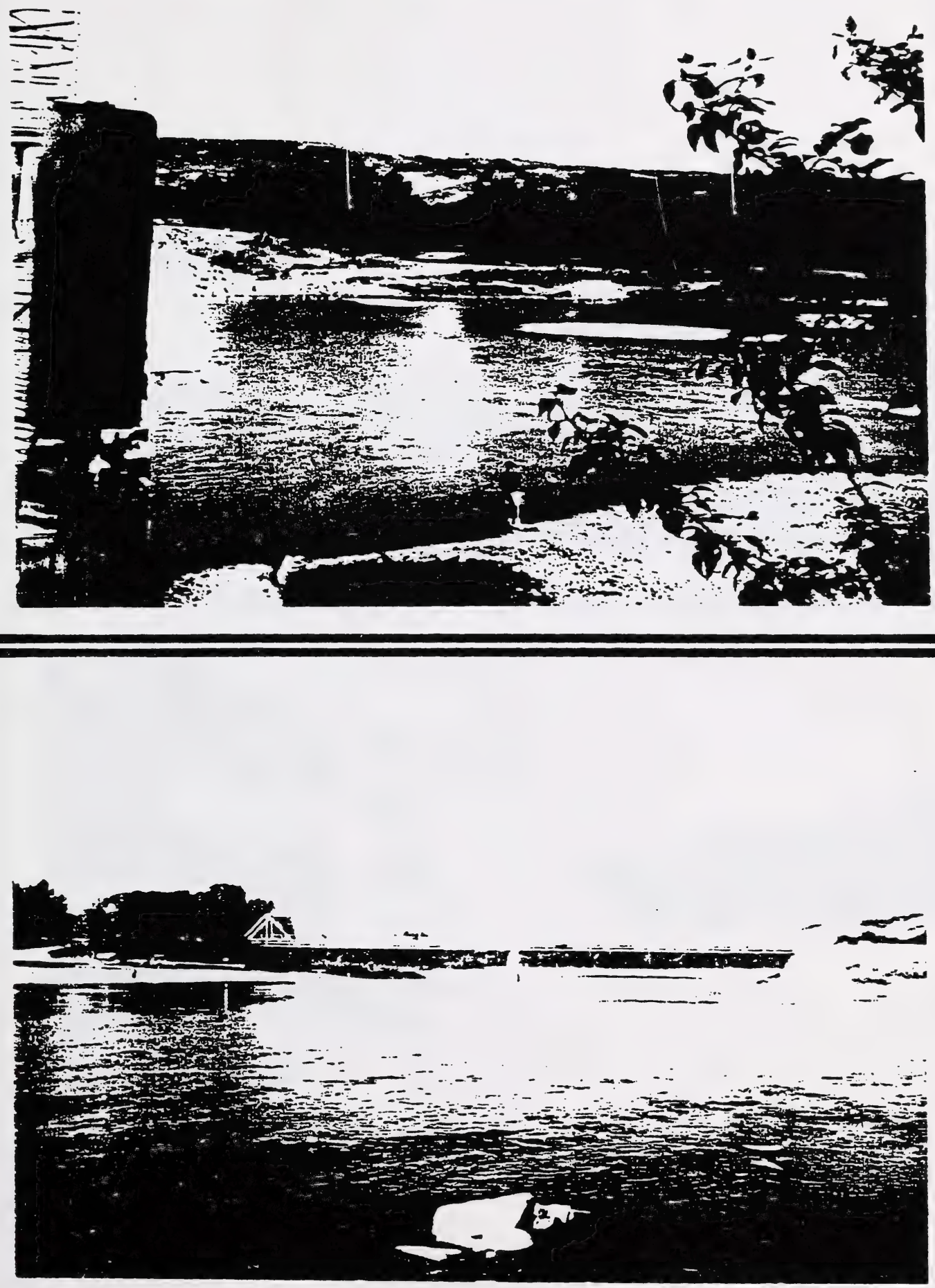


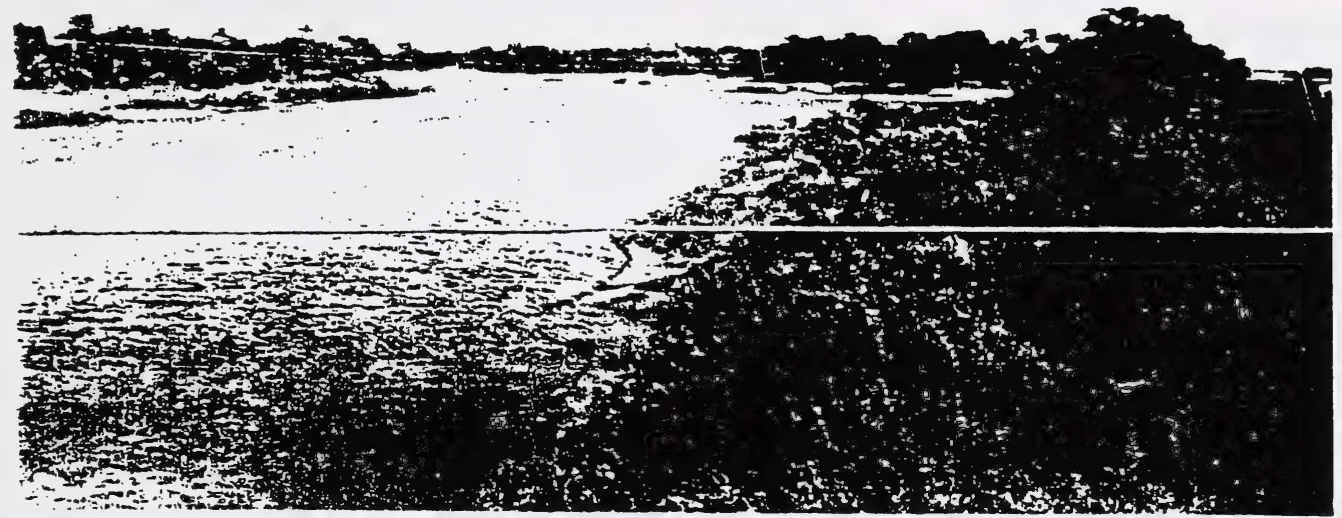

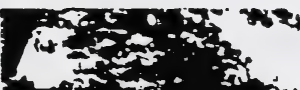

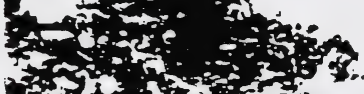

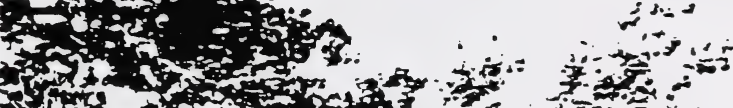

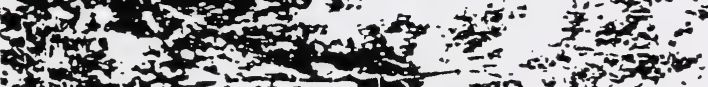

ton

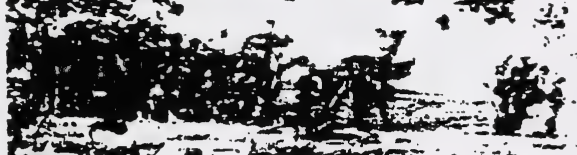

(c)

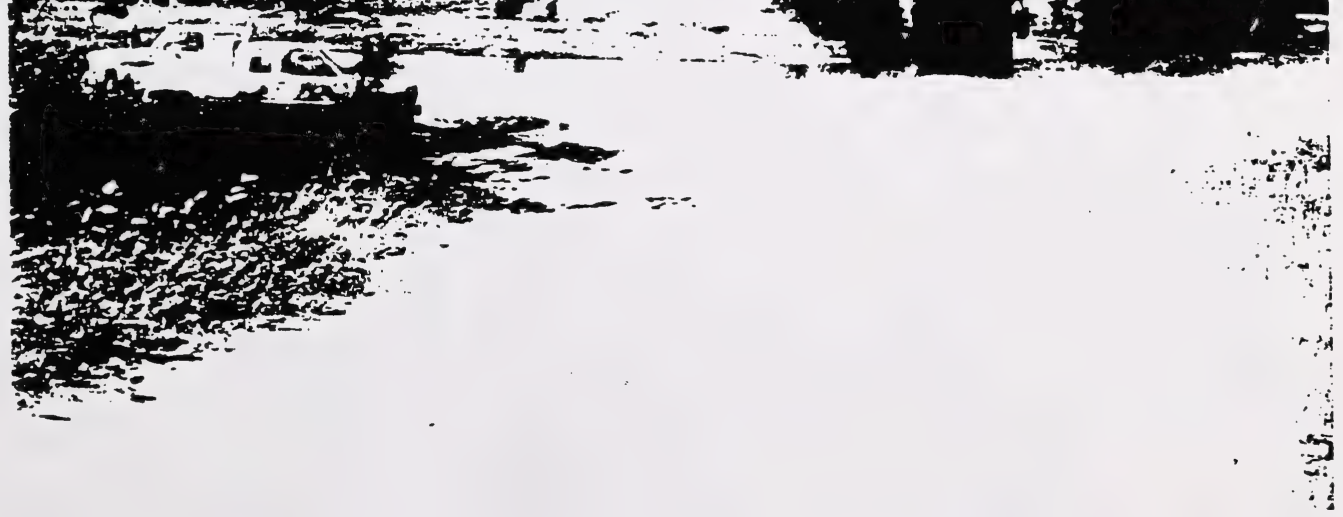

Phot 



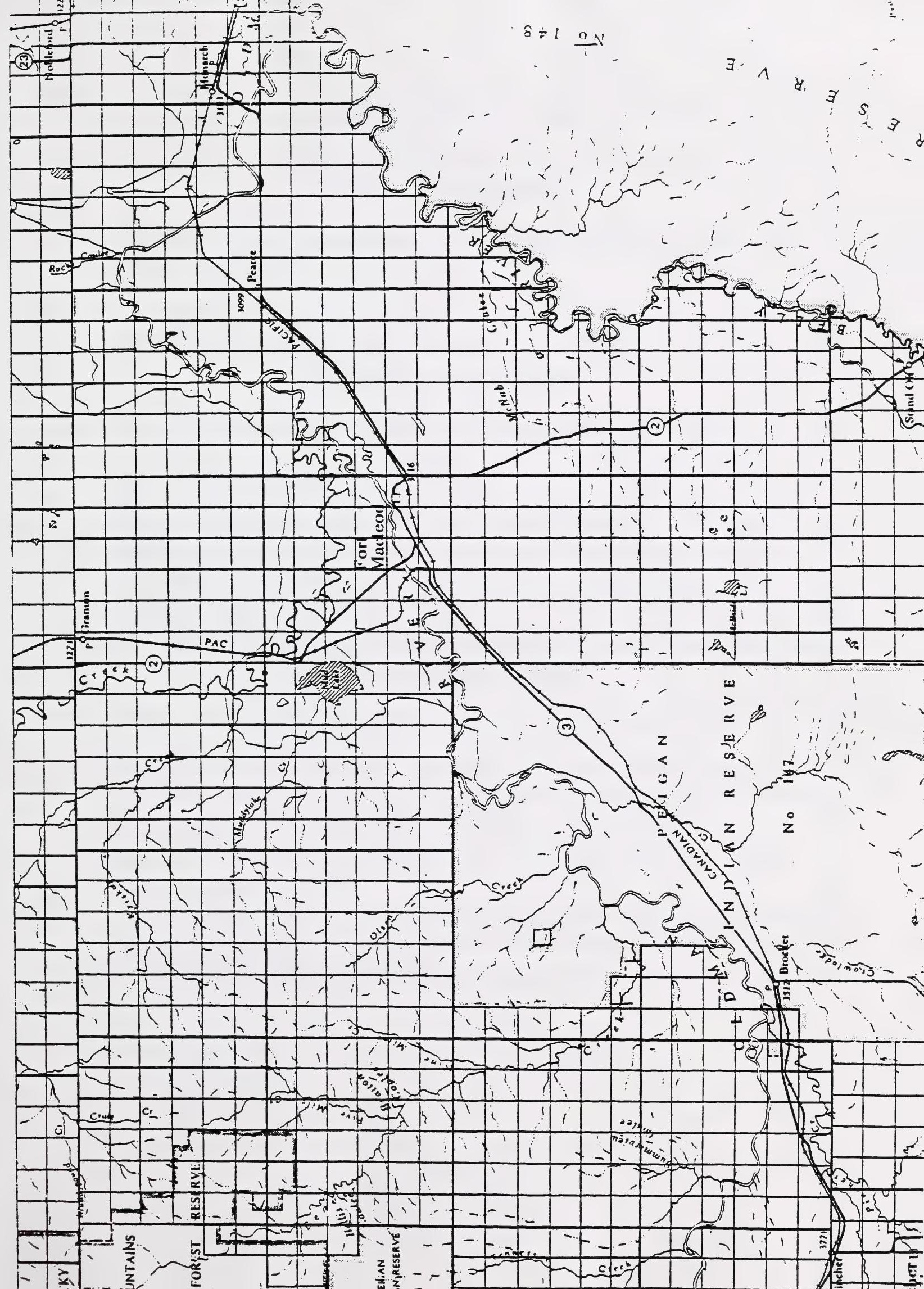



Table 1. 1996 Sportfishing Regulations for the Oldman River within the study area (adapted from Alberta Guide to Sportfishing, 1996)

\section{Province Wide Limits}

- 5 trout and Arctic grayling combined, of which none may be Bull trout (Dolly Varden)

- 10 Mountain whitefish

- 3 Walleye and sauger combined

- 10 Northern Pike

- 10 Goldeye

\section{Fish Management Area 1}

NOTE: Province-wide sportfishing regulations apply, with the following exceptions:

Waters are open to fishing all year.

11 Bull trout (Dolly Varden) must be released. If no black, put it back (dorsal fin).

Walleye and Sauger combined limit is 3 . All walleye populations in FMA1 are classified as Vulnerable (minimum size $50 \mathrm{~cm}$.) All walleye shorter than $50 \mathrm{~cm}$. in total length must be released.

Bait Fish - the use of bait fish and the collection of bait fish are allowed.

Exempt from Bait Ban.

\section{Fish Management Area 2}

NOTE: Province-wide sportfishing regulations apply, with the following exceptions:

11 Bull Trout (Dolly Varden) must be released. If no black, put it back (dorsal fin). All Rainbow and Cutthroat Trout shorter than $25 \mathrm{~cm}$. In length taken from any flowing waters, except from portions of the Crowsnest River must be released..

Walleye and Sauger combined limit is 3. All walleye populations in FMA2 are classified as Vulnerable (minimum size $50 \mathrm{~cm}$.). All walleye shorter than $50 \mathrm{~cm}$ in total length must be released.

Bait fish - the use of bait fish and the collection of bait fish are prohibited in all waters. The portion between the Oldman Reservoir and the first bridge down stream located in SE16-7-29-W4, open all year; bait ban. 



\section{INTRODUCTION}

From what I was able to ascertain, a previous creel survey has not been conducted

on the Oldman River downstream of the Oldman River Dam. This study began with orientation to the study area to determine access points used by anglers.

\section{STUDY AREA}

The study area consisted of the Oldman River from the Oldman River Dam approximately 10 kilometers north east of the town of Pincher Creek, downstream to the Highway \#3 bridge over the Oldman River approximately 4 kilometers south west of the town of Monarch (Figure 1). The stretch of the Oldman River which flows through the Peigan First Nation Reservation was not studied in this survey.

The study area was broken down into different reaches of the river which included:

- Oldman River Dam to the first bridge down stream which this report will refer to as the Cottonwood bridge.

- Cottonwood bridge to the east boundary of the Cottonwood Campground, which for the purposes of this study was considered the Day Use Area, which this report will refer to as the Cottonwood Day Use. 


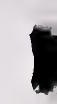

1

I

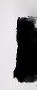

,

I

।

I

I

,

I

I

।

I

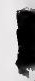

।

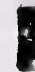

1 
- East boundary of the Cottonwood Campground to the Summerview bridge which is the next bridge downstream of the Cottonwood bridge.

- Summerview bridge to the west boundary of the Peigan First Nation Reservation.

- East boundary of the Peigan First Nation Reservation to Highway \#2.

- Highway \# 2 to the east boundary of the town of Fort Macleod, which for the purposes of the study was considered the Girl Guide Camp.

- East boundary of Fort Macleod to the Highway \#3 bridge over the Oldman River approximately 4 kilometers south west of the town of Monarch, which this report will refer to as the Monarch bridge.

Eleven access sites to the river used by anglers were identified. Of these eight sites, six were within the Oldman River Dam PRA.

These sites included:

- West Boulder Run, where anglers parked their vehicles and walked to the river (Photo 1).

- East Boulder Run, where anglers parked their vehicles and walked to the river (Photo 2).

- Cottonwood Boat Launch, where anglers launched boats and parked vehicles (Photo 3).

- Cottonwood Campground. Some anglers were camping overnight and walked to the river from their campsite, others parked in the campground while angling but did not stay overnight (Photo 4).

- Cottonwood Day Use, where anglers parked their vehicles and walked to the river (Photo 5). 

- Oldman River Park. Some anglers were camping overnight and walked to the river from their campsite, others parked in the campground while angling but did not stay overnight (Photo 6).

The five access points surveyed which were not within the Oldman River PRA included:

- NE shore of Summerview bridge. A gravel access road allows anglers to park their vehicles next to the shore (Photo 7)

- SE shore of Summerview bridge. A gravel access road allows anglers to park their vehicles next to the shore. (Photo 8)

- NE shore of 6th Avenue bridge in Fort Macleod. A gravel access road to a Girl Guide Camp provides anglers access to park their vehicles next to the shore (Photo 9).

- SE shore of 6th Avenue bridge in Fort Macleod. A gravel access road allows anglers to park their vehicles next to the shore (Photo 9).

- NW shore of Monarch bridge. A gravel access road allows anglers to park their vehicles next to the shore (Photo 10). The west shore is used by anglers to a maximum of approximately 50 meters up or down stream of the bridge. There is no vehicle access to the east shore nor evidence of angler use along it.

The only public access points to the Oldman River discovered within the study area located outside the Oldman River Dam PRA are the Summerview bridge, within the town of Fort Macleod where the Oldman River passes through, and the Highway \#3 bridge approximately $4 \mathrm{~km}$ west of the town of Monarch. 

The study area lies within two Fish Management Areas which are FMA1 and FMA2 (Alberta Guide to Sportfishing, 1996). For the Oldman River, the boundary for FMA1 and FMA2 is Highway \#2.

FMA1 - includes the Oldman River within the study area between Highway \#2 and the Monarch bridge.

FMA2 - includes the Oldman River within the study area between the Oldman River Dam and Highway 2.

A summary of the 1996 Sportfishing Regulations pertaining to the Oldman River within the study area is listed in Table 1

- The portion between the Oldman Reservoir and the first bridge down stream located in SE16-7-29-W4, open all year; Bait Ban

\section{METHODS}

Upon orientation with the study area, a random roaming approach was best suited to the study considering the factors that only one person would be collecting field data, and the study area is very large. Direction was given to focus the field survey within the Oldman River Dam PRA and conduct random periodic surveys within the rest of the study area. A random periodic survey was conducted from the east boundary of the Peigan First Nation Reservation to the Monarch bridge one week day and one weekend day per week. 

Since more angling occurred in the evening and on weekend days, an attempt was made to spend as much of that time as possible conducting surveys.

Considering the purpose of a recreational use demographical creel survey and the expected activity within the study area, a field survey form was created to include the following data:

- The date, to provide demographics as to angling pressure based on day of the week.

- The time of day, to provide demographics as to the times of day that angling pressure is high and low.

- The weather conditions, to provide the effects of weather on the angling pressure and success of anglers.

- The river conditions (water turbidity, temperature, and flow rate), to provide the effects of river conditions on angling success.

- The reach of the river within the study area, to provide demographics as to areas with low and high angling pressure.

- Access point anglers use, to provide input for management planning of the Oldman River Dam PRA.

- The type of angling equipment being used, to provide demographics as to the user groups of the Oldman River fishery.

- The residence of the angler, to provide demographics as to the proximity of the users of the Oldman River fishery within the study area.

- Whether the angler was staying overnight in the Oldman River Dam PRA or only day using, to provide input for management planning of the Oldman River Dam PRA. 


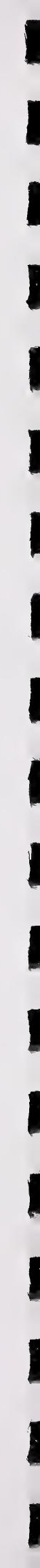


- If the angler was staying overnight in the Oldman River Dam PRA, which campground was being used, to provide input for management planning of the Oldman River Dam PRA.

- Whether the angler was angling from shore, wading in the river wearing angling waders, or using a boat; to provide demographics as to the user groups of the Oldman River fishery. Another consideration in collecting this data was the probable threat of the spread of whirling disease (Myxobolus cerebralis) into the Oldman River from the United States through contaminated angler equipment.

- Whether the angler was alone or with other anglers, to provide demographics as to the user groups of the Oldman River fishery.

- The number of hours spent angling to use in calculating statististics on angling pressure (catch per unit effort)

- Number of fish caught (including released fish) and the number of fish kept, to provide demographics as to the angler harvest pressure.

- To simply provide data on angler awareness / understanding of the sportfishing regulations within the study area.

- Frequency of angling within the study area, to provide demographics as to the angling pressure.

- Angler harvest practices, to provide demographics as to the angling pressure within the study area. 

Data on the fish kept by anglers including: species, fork length, weight, girth, and scale sample. Data was only collected on Rainbow Trout based on direction received that data was not necessary for Mountain Whitefish and Goldeye which were the only other species anglers possessed. Incidentally, most Mountain Whitefish harvested were "gutted" immediately and the only data which would have been meaningful would have been a fork length. Unless fish were kept by anglers, measurement statistics and scale samples were not obtained.

- Gender of the angler, to provide demographics as to the user groups.

- Age group of the angler, to provide demographics as to the user groups. The age groups used included youth (less than 16 years old), adult (16 - 64 years old), and senior (65 years old or older) since these are the age groupings in the Sportfishing Regulations pertaining to sportfishing licence requirements. All persons except youths under 16 years old and Alberta residents 65 years and older sportfishing in Alberta are required to hold a sportfishing licence (Alberta Guide to Sportfishing, 1996).

\section{RESULTS}

It was determined through angler surveys and two days spent assisting with an electro-fishing project to transport Bull Trout (Salvelinus confluentus) to suitable spawning habitat that the sportfish present in the Oldman River within the study area comprised of the following species: 

- Rainbow Trout (Oncorhynchus mykiss)

- Mountain Whitefish (Prosopium williamsoni)

- Brown Trout ( $\underline{\text { Salmo trutta) }}$

- Bull Trout (Salvelinus confluentus)

- Cutthroat Trout (Oncorhynchus clarki)

- Northern Pike (Esox lucius)

- Goldeye (Hiodon alosoides)

Other non-sportfish recorded included the following species:

- Burbot (Lota lota)

- Longnose sucker (Catastomus catastomus)

- White Sucker (Catastomus commersoni)

All anglers staying overnight in the proximity of Cottonwood Campground stay in Cottonwood Campground or Chinook R.V. Park. Those staying overnight in the proximity of Oldman River Park stay at Oldman River Park. None of the anglers interviewed were staying overnight in any of the other camping areas within the Oldman River Dam PRA such as Island View. Many anglers staying overnight in the PRA fish periodically throughout the day.

Weekend days and evenings were the busiest times, however, this is not reflected in the number of surveys conducted each day since all potential anglers could not be surveyed during busy periods. 

Most anglers are aware of the sportfishing regulations pertaining to Bull Trout. Many who catch and release are only moderately aware of the sportfishing regulations, claiming that if you do not fish with bait and you release all the fish you catch you do not need to concern yourself with sportfishing regulations. Few anglers are confident they are aware of all sportfishing regulations pertaining to the area they are in. Many anglers have a perception that the sportfishing regulations are complicated and intimidating so they do not read the guide. They are, however, very receptive to having someone go over them with them since most anglers want to comply with the regulations and are supportive of regulations to protect the fishery. Some commented that they would like to see the limit on Rainbow Trout reduced from five to two, as a proactive step to assure a sustainable fishery as angling pressure increases.

There is a misconception by some that the Rainbow Trout population in the Oldman River is enhanced. Some anglers release fish they believe are from wild populations but will keep fish that are enhanced "put and take" fishery.

Flood damage reclamation projects took place during the study period which increased the turbidity of the water and deterred anglers. Following is a list of these projects as observed:

- Monday, July 29 heavy equipment (excavators, loaders) was observed in the Oldman river down stream of the 6th Avenue bridge in Fort Macleod. This work continued through duration of study period.

- Friday, August 16 observed heavy equipment is also in the Oldman river up stream of the 6th Avenue bridge in Fort Macleod. 

- Monday, August 12 heavy equipment was observed in the Oldman river between the Oldman Dam and the Cottonwood bridge for Boulder Run reclamation repairs. This work continued through duration of study period. Previous to today muddy water must be from work in the Crowsnest and Castle Rivers and heavy winds last week. Sunday, August 18 noticed signs erected at East Boulder Run stating , "NO PARKING" and "NO UNAUTHORIZED VEHICLES BEYOND THIS POINT".

Monday, August 12 observed heavy equipment in Castle River just downstream of Cowley-Lundbreck Rodeo Grounds and in Crowsnest River downstream of Lundbreck Falls approximately $2 \mathrm{~km}$ upstream of Todd Creek Day Use Area. The consultant overseeing the work advised they are just finishing the repairs to fisheries habitat enhancement structures in the Crowsnest and Castle Rivers damaged by the flood of June 1995. They worked August 1, 2, and 6 to 10 inclusive. He advised he would be surprised if their work was having much impact on the turbidity of the Oldman River downstream of the Dam. They are next going to place the boulder piled on Leroy Oberton's property just upstream of the Summerview bridge, and that is all for this season. He doesn't know about Boulder Run work and Fort Macleod work.

- Heavy equipment was also observed in the Oldman river just downstream of Cottonwood bridge the week of August 12. This work was done to replace an irrigation pump which had been lost in the flood of June 1995.

Rainbow trout is the most abundant sportfish in the stretch of the Oldman River from the Oldman River Dam downstream to the west boundary of the Peigan First Nation Reservation, and is the most sought after species by anglers. 

The second most abundant species is the Mountain Whitefish which some anglers specifically angle for. Other species caught and observed during electro-fishing in this stretch of the river include Bull Trout, Brown Trout, Northern Pike, Cutthroat Trout, Burbot, Longnose Sucker, and White Sucker.

Based on fish caught by anglers downstream of the east boundary of the Peigan First Nation Reservation, the most abundant sportfish is the Brown Trout, which has been enhanced in the proximity of the ORP. Other species caught by anglers in this stretch of the river include Rainbow Trout and Goldeye. Other species probably present in the stretch of the river include Mountain Whitefish, Bull Trout, Cutthroat Trout, Northern Pike, Burbot, Longnose Sucker, and White Sucker.

The study area is situated in a section which receives heavy winds periodically and deters anglers.

Some anglers commented that there is inadequate access to the Oldman River outside the Oldman River PRA. No public access to the Oldman River was discovered between Fort Macleod and Monarch bridge.

Some anglers expressed concern about the spread of whirling disease into the Oldman river which could potentially destroy the fishery.

Angling is subject to so many variables:

- angler skill level, weather and time of day 



\section{Oldman River Dam Provincial Recreation Area Down Stream Creel Census}

Date Interview Time: Start Finish

Weather Temperature

$\square$ - Sunny

$\square$ - Windy

$\square$ - Partly Cloudy

$\square$ - Cloudy

Water Temperature Flow Rate

River Conditions

$\square$ - Muddy

$\square$ - Clearing

$\square$ - Light Wind

$\square$ - Calm

$\square$ - Dam to Bridge $\square$ - Bridge to Cottonwood E.

$\square$ - Clear

$\square$-Summerview to Reserve $\square$-Reserve to Highway $2 \square$-Highway 2 to Fort MacLeod

$\square$ - Fort MacLeod to Monarch

Access Point

Fishing equipment

$\square$ - Fly fishing gear

$\square$ - Spinning fishing gear

$\square$-Fly $\square$-Bait $\square$-Lure

$\square$ - Staying Overnight in PRA Which campground?

Residence

$\square$ - Alberta Resident/Day Use

Residence?

$\square$ - Non-Alberta ResidendDay Use Residence?

$\square$-Fishing from shore $\square$-Wading $\square$-Boat

$\square$-Fishing Alone $\square$. Fishing with others, Number in group

Number of hours fished

Hours fished

NUMBBER OF FISH CAUGHT (including released fish)

\begin{tabular}{|l|l|l|l|l|}
\hline INBOW TROLT & BROWN TROUT & BULI TROUT & MOUNTAIN WHITEFISH & OTHER (SPECIFY) \\
\hline & & & & \\
\hline
\end{tabular}

NUMBEER OF FISH KEPT

\begin{tabular}{|l|l|l|l|l|}
\hline INBOW TROUT & BROWN TROUT & BULL TROUT & MOUNTANN WHITEISH & OTHER (SPECIFY) \\
\hline & & & & \\
\hline
\end{tabular}

Anglers estimate of length of fish released

Anglers estimate of weight of fish released

Aware of/understand fishing regs in area

$\square$ - Definitely $\square$-Moderately $\square$ - Not at all

Fish the Oldman River $\square$-Frequently $\square$-Occasionally $\square$-First Time

Harvest Practices $\square$-Strictly Catch and Release $\square$-Keep One or Two $\square$ - Keep Limit Anglers Comments: 


\section{Fish Statistics}

\begin{tabular}{|c|c|c|c|c|c|c|}
\hline SPECIES & $\begin{array}{c}\text { FORK } \\
\text { LENGTH }(\mathrm{cm})\end{array}$ & $\begin{array}{l}\text { WEIGHT } \\
(\mathrm{kg})\end{array}$ & $\begin{array}{l}\text { GIRTH } \\
(\mathrm{cm})\end{array}$ & $\begin{array}{c}\text { SCALE SAMPLE } \\
\text { NUMBER }\end{array}$ & KEPT & RELEASED \\
\hline & & & & & & \\
\hline & & & & & & \\
\hline & & & & & & \\
\hline & & & & & & \\
\hline & & & & & & \\
\hline & & & & & & \\
\hline & & & & & & \\
\hline & & & & & & \\
\hline & & & & & & \\
\hline & & & & & & \\
\hline & & & & & & \\
\hline & & & & & & \\
\hline & & & & & & \\
\hline & & & & & & \\
\hline
\end{tabular}

Interviewers Comments'Observations:

$\square$ - Male $\square$-Female

$\square$-Child $\square$-Adult $\square$.Senior 



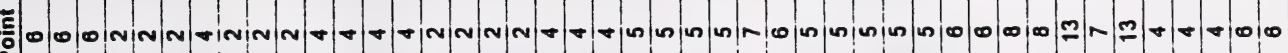

-

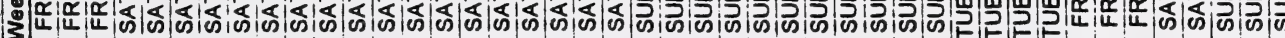

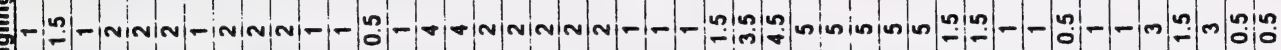

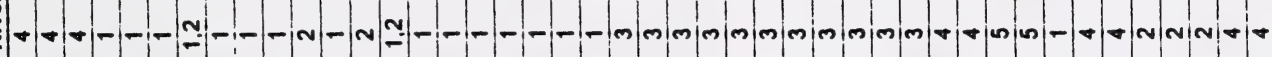
केष

วิ:

난-

वे>

ఫัँّ

๘ँ

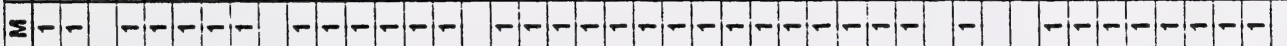

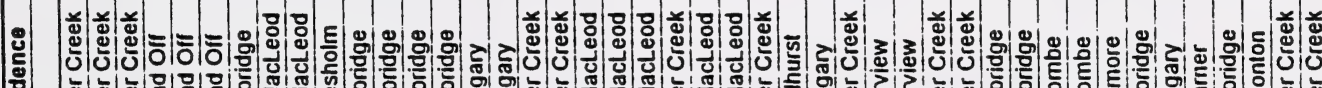

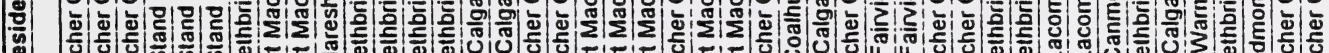

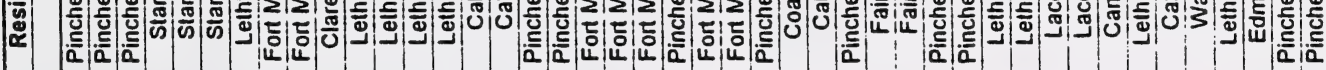

窟:

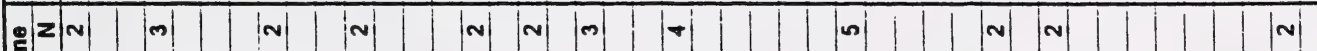
웅

\&

\begin{tabular}{|c|c|c|c|c|c|c|c|}
\hline & $-|-| \leqslant|\leqslant| \leqslant|\leqslant| \leqslant \mid$ & |s & & $|\leq| \leq|\leq| \leq|\leq| \leq|\leq| \leq|\leq| \leq|\leq| \leq|\leq| \leq \mid$ & 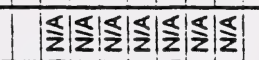 & & \\
\hline & z|s|s|s|s| & s & -- & $-1-|\leq| \leq|\leq| \leq|\leq| \leq|\leq| \leq|\leq| \leq|\leq| \leq \mid$ & 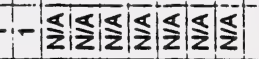 & 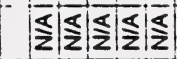 & \\
\hline & $|\leq| \leq|\leq| \leq \mid$ & & & $|\leq| \leq|\leq| \leq|\leq| \leq|\leq| \leq|\leq| \leq|\leq| \leq|\leq|$ & $|\leqslant| \leqslant|\leqslant| \leqslant|\leqslant| \leqslant \leqslant$ & $-|\leq| \leq|\leq| \leq|\leq| \leq \mid$ & \\
\hline
\end{tabular}

:

$\frac{\infty}{3}$

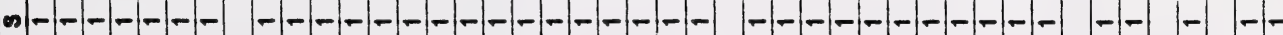

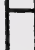

$\because$

$-\infty$

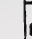

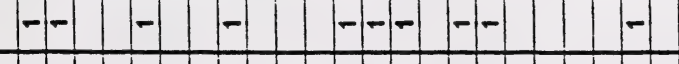

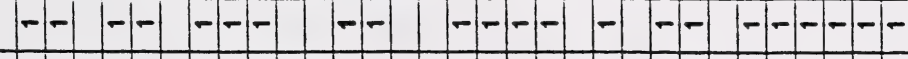





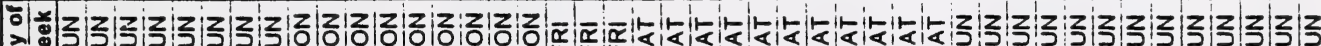

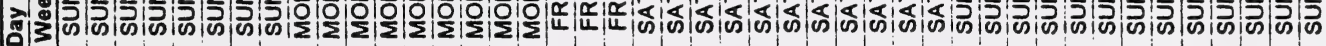
药 कิธ

임os

은

:

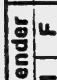

छ

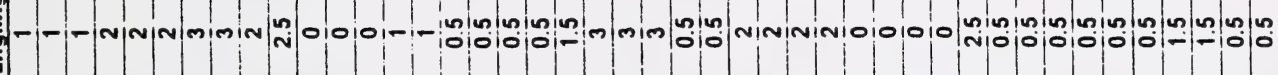

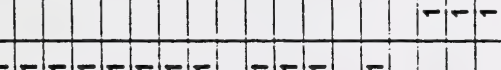

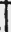

4

()

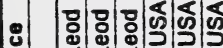

:

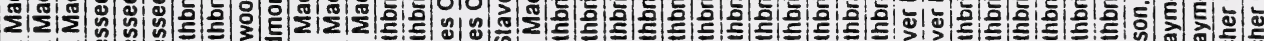

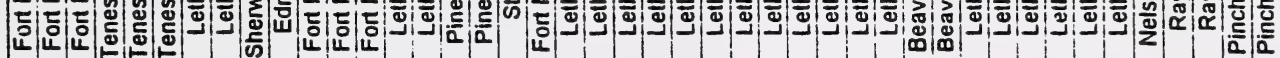

\begin{tabular}{|c|c|c|c|c|c|c|c|c|c|c|c|c|c|c|c|c|c|c|c|c|c|}
\hline 0 & & & & & & $1-$ & -1 & -1 & $-1-$ & & F & -1 & $-1-i$ & $-r-r$ & -- & -1 & & $---1-1$ & - & & - \\
\hline $\begin{array}{l}5 \\
\frac{\pi}{2}\end{array}$ & --1 & $-1-1$ & & -1 & & & & & 1 & $1-$ & $-1-1$ & & & & & $-1-$ & $-1-1$ & -1 & 1 & & \\
\hline$=2$ & & $m$ & & $\mathbf{n}$ & & $m$ & . & $N$ & in & & on & & $|\sim|$ & + & & & N & mi & $n$ & & $\sim$ \\
\hline & & & & & & -1 & & & 1 & $1-\mid$ & $-1-$ & & & & & $-1-$ & & - & -1 & & \\
\hline . & $|\S| \mathbf{z}$ & & & & & $\mid \mathbf{z}$ & & & $|\underline{z}| \underline{z}$ & & & & & & & & & -1 & & & \\
\hline$\omega$ & $\overline{\mathbf{z}} \mathbf{z}$ & & & & & $\mathbf{s}$ & & & $-|\leq| \leq|\leq|$ & & $-1-$ & & -1 & & -- & - & & & - & & \\
\hline & $|\mathbf{z}| \mathbf{z}$ & & & $\Gamma$ & & $\mid \frac{5}{z}$ & & & $|\mathbf{z}| \mathbf{z}$ & & & & & $1-1$ & & $-1-$ & -1 & $|-|-1$ & -1 & & \\
\hline$\infty$ & & & & & & & & & & & & & & & & & -1 & & & & \\
\hline & & - & & & & - & & & & & - & & & & & -1 & & & & & \\
\hline$\infty$ & $-1-$ & & & & 5 & - & & & $-1-$ & $-1-$ & -1 & - & -1. & -- & $--1-$ & & & ------ & --1 & & - \\
\hline & & & & & & & & & & $-1-$ & $-1-$ & $-1-$ & - & -1 & $1-1$ & & & $1----1-1$ & $-1-1-$ & & \\
\hline & & & & & & & & & & - & & & & & & & & - & & & \\
\hline & & & & & & $-1-$ & $-1-$ & $-1-$ & & & - & & -1 & - & & $-1-$ & & - & & & \\
\hline & & & & & & & & & & & $-1-$ & $-1-$ & & -5 & -- & & & ------ & $--1-$ & & - \\
\hline 4 & & & & & & - & & & & & & & - & - & & -- & -- & & & & \\
\hline$\frac{5}{2}$ & & & & & & h. & & & 요잉 & $5|8| 8$ & :|ळ!: & $3: 1 \%$ & 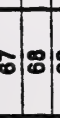 & 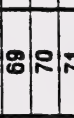 & & $2=16$ & & ๑) & $\Phi \infty$ & & $\infty$ \\
\hline
\end{tabular}



min

$\operatorname{mon}$

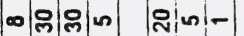

$\cong \cong$

>

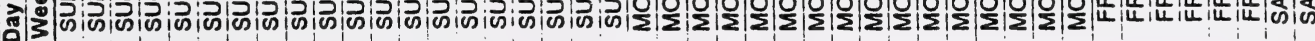

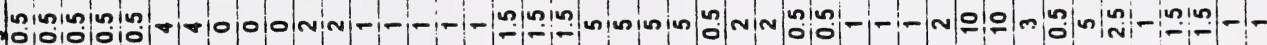

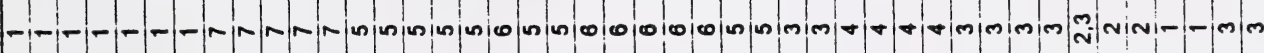
ติธ

익o

인.

햔ㄴ

$\Sigma$

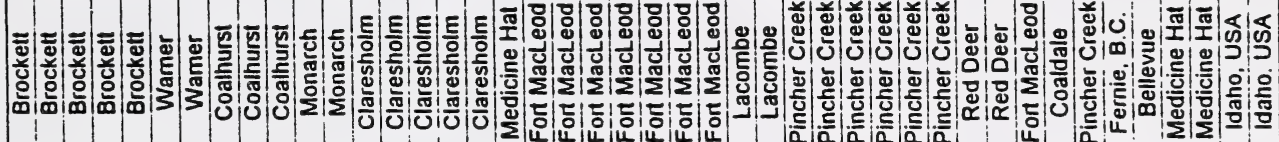

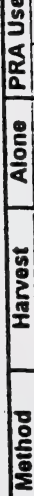

$\$$

$2=\ln$

$|n| \operatorname{mo}|\operatorname{nn}| \ln !$

$111 / 0101$

$---1-$

$<-1-1-1-1---1--$

$1+1-1-1-1-1$

$-1--1-1---1-$

$<$

(1)

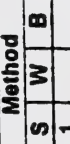

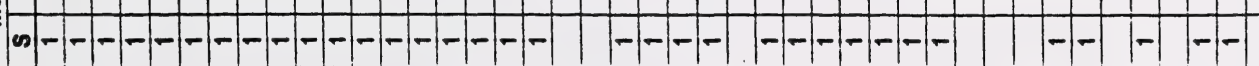

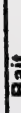

䒽向

$-1-1-1-$

$1-1-2-1-$

$-1--1-1--$

$-\frac{1}{-1---}$

1

1

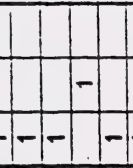

$-1$

(1)

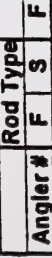
$-1--1-\infty-1$ $-$ 



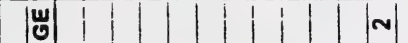

Fトト

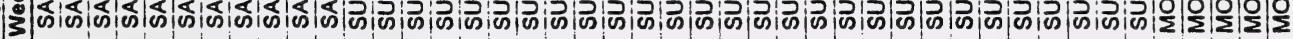

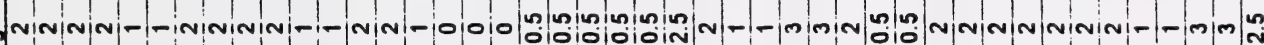

\section{$\sum_{x}$}

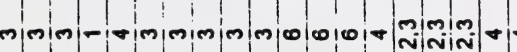
$\frac{1}{1+1}$

\footnotetext{
1
}

递

$\Sigma-$

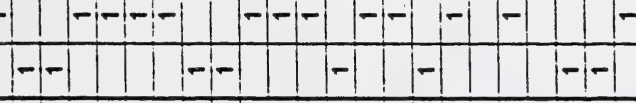

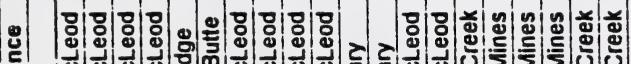

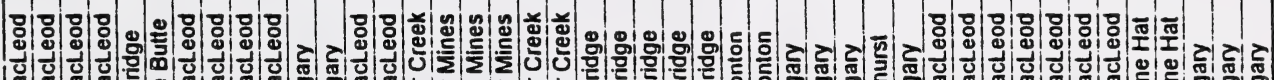

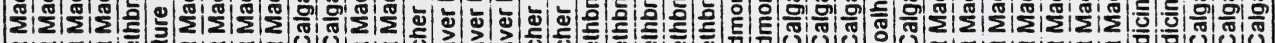

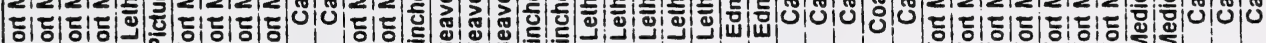

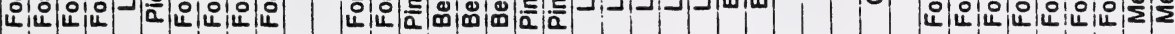

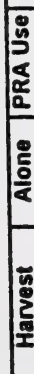

îjo-

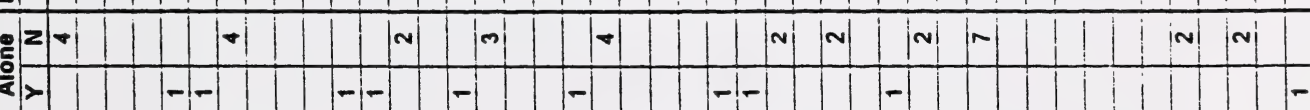





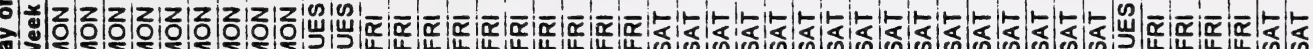

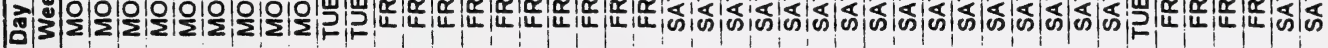

늘 吾ojo구

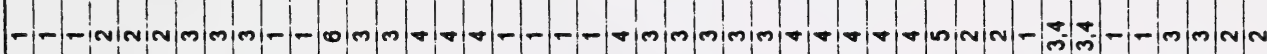
कें)

잏요

:

햔

ฮั $\Sigma$

$m|-n| n-$

$1-1-$

$\lim _{-1-\infty}|-|-\mid-1$

11

1111110

$\frac{11}{-1-1}$

$\left.\right|_{-1-1}|-1-1-1|||$

$>$

$-11111111111-1$

111111111110

1

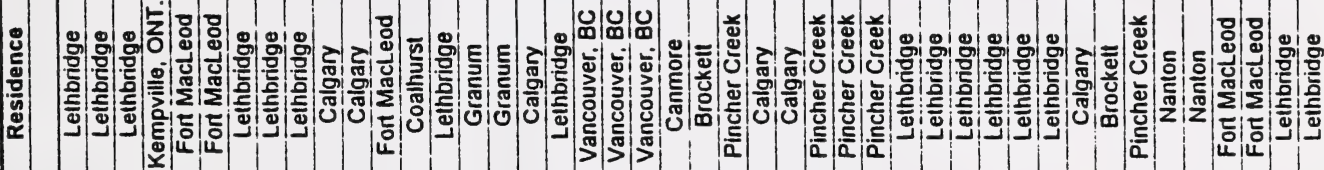

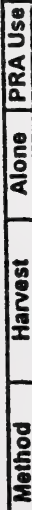

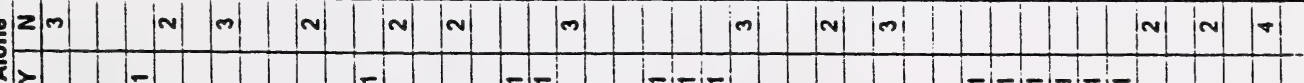

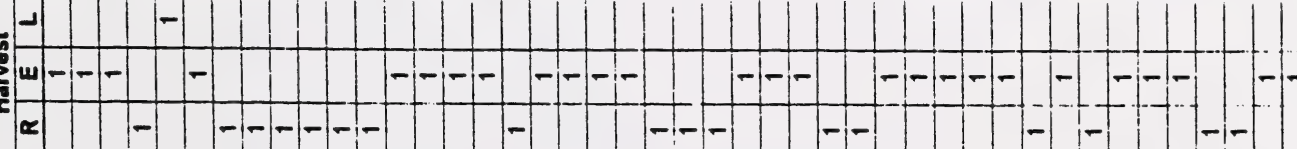

要

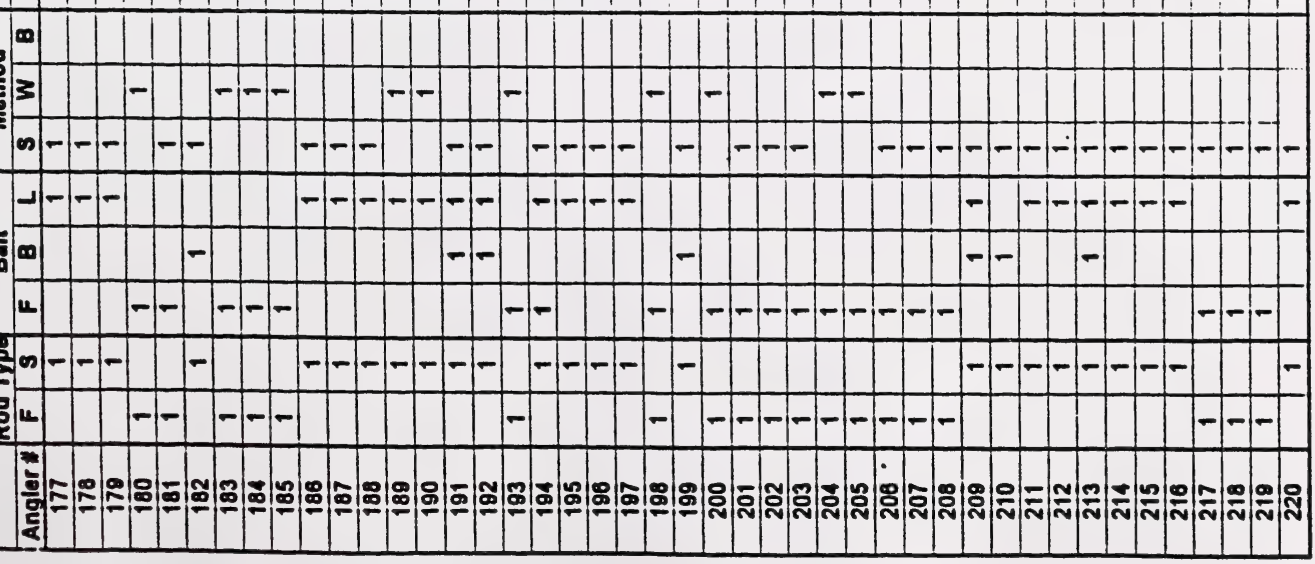







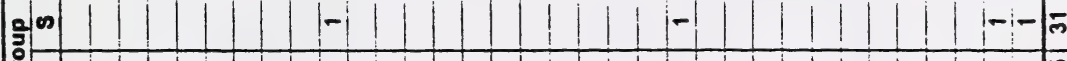

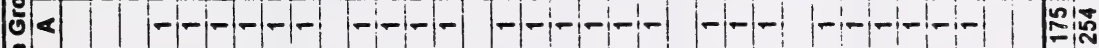

क्षे|-

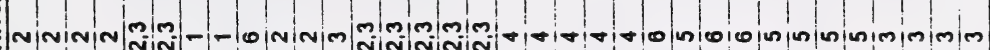
\%)

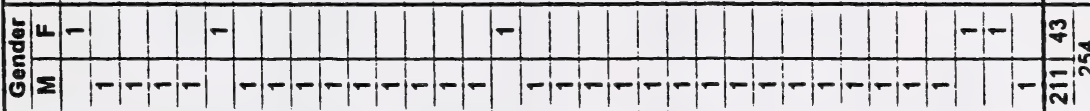

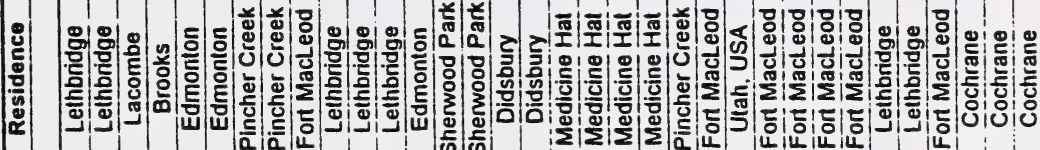

\begin{tabular}{|c|c|c|c|c|c|c|c|c|c|c|c|c|c|c|c|c|c|}
\hline 0 & - & & & & & 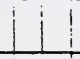 & 1 & & 1 & 1 & & & & 111 & 1 & $1-$ & 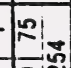 \\
\hline - & & & -1 & -1 & & $-r$ & -1 & -1 & $-i-$ & - & -- & $-1-$ & & --- & $-1-$ & $--\quad$ & $\underbrace{g}$ \\
\hline$z$ & & r & v & $n \mid$ & & & m & n & $1+$ & & & & & $|\sim||N|$ & & $m$ & $\Phi$ \\
\hline & & & & & & $-1-1$ & & & 1 & & & & - & & $1-1-$ & --1 & 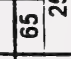 \\
\hline & & & & & & -1 & & & 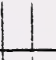 & & & -1 & & & & & \\
\hline 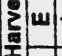 & -1 & & & & - & & & & 1 & & & & & $1-1-$ & - & $-1--$ & \\
\hline & & -1 & -1 & H & - & & -1. & -1 & -1 & & & - & - & & & $-11:$ & 2 \\
\hline$\infty$ & & & -1 & & & & -1 & & -1 & & & & & & & & \pm \\
\hline & & - & & & & & & & & & & - & - & & & & $\mathbb{8}$ \\
\hline & $E$ & & & - & & $-1-$ & & & - & & & $1-$ & I & - & $-1-$ & $--1-1-$ & : \\
\hline & & & & - & & --1 & & & & & $-1-$ & & - & $1-1-$ & & & \\
\hline & & & & & & -1 & & & & & & - & & $-1-$ & & ---- & $-\infty$ \\
\hline & & & & - & - & & & & $-1-$ & - & & - & - & & -1 & -1111 & \\
\hline & & & & $-F$ & & -- & & & & & -5 & & & $1-1-5$ & & $-1-1$ & 18 \\
\hline & & -5 & & & - & & -5 & & $-1-$ & -1 & & - & -1 & & - & -11 & 8 \\
\hline & & & & & & & & & 5 & & & & & $\infty$ & $\$ 0$ & 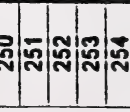 & \\
\hline
\end{tabular}



Statistics for Rainbow Trout Harvested

\begin{tabular}{|l|l|l|l|}
\hline Fork Length $(\mathrm{cm})$ & Weight $(\mathrm{g})$ & Girth $(\mathrm{cm})$ & Scale Sample \# \\
\hline
\end{tabular}

\begin{tabular}{|c|c|c|c|}
\hline 37 & 580 & 18.5 & 1 \\
\hline 37.5 & 650 & 21 & 2 \\
\hline 38 & 700 & 19 & 3 \\
\hline 32.5 & 400 & 18 & 4 \\
\hline 40 & 600 & 19 & 5 \\
\hline 35 & 500 & 19.2 & 6 \\
\hline 35 & 500 & 18 & 7 \\
\hline 35.4 & 550 & 19.6 & 8 \\
\hline 38 & 650 & 21 & 9 \\
\hline 33 & 425 & 18 & 10 \\
\hline 27 & 275 & 15.5 & 11 \\
\hline 49 & 1150 & 25 & 12 \\
\hline 36 & 500 & 18.5 & 13 \\
\hline 39 & 600 & 19.5 & 14 \\
\hline 32 & 325 & 16.5 & 15 \\
\hline 38 & 650 & 21 & 16 \\
\hline 40 & 725 & 21.5 & 17 \\
\hline 37.5 & 550 & 19.5 & 18 \\
\hline AVERAGE & AVERAGE & AVERAGE & \\
\hline 36.7 & 574 & 19.4 & \\
\hline & & & \\
\hline
\end{tabular}





\begin{tabular}{|l|c|c|}
\hline \multicolumn{2}{|c|}{ STATISTICS FOR PROXIMITY OF ANGLERS } \\
\hline RESIDENCE & NO. OF ANGLERS & PERCENTAGE \\
\hline Letht,ridge & 60 & $23.6 \%$ \\
\hline Fort MacLeod & 51 & $20.1 \%$ \\
\hline Pincher Creek & 32 & $12.6 \%$ \\
\hline Calgary & 19 & $7.5 \%$ \\
\hline Medicine Hat & 9 & $3.5 \%$ \\
\hline Brockett & 7 & $2.8 \%$ \\
\hline Edmonton & 7 & $2.8 \%$ \\
\hline Claresholm & 6 & $2.4 \%$ \\
\hline Coalhurst & 6 & $2.4 \%$ \\
\hline Beaver Mines & 5 & $2.0 \%$ \\
\hline Lacombe & 5 & $2.0 \%$ \\
\hline Stand Off & 3 & $1.2 \%$ \\
\hline Warner & 3 & $1.2 \%$ \\
\hline Tenessee, USA & 3 & $1.2 \%$ \\
\hline Sherwood Park & 3 & $1.2 \%$ \\
\hline Vancouver, BC & 3 & $1.2 \%$ \\
\hline Cochrane & 3 & $1.2 \%$ \\
\hline Fairview & 2 & $0.8 \%$ \\
\hline Canmore & 2 & $0.8 \%$ \\
\hline Raymond & 2 & $0.8 \%$ \\
\hline Monarch & 2 & $0.8 \%$ \\
\hline Red Deer & 2 & $0.8 \%$ \\
\hline Idaho, USA & 2 & $0.8 \%$ \\
\hline Granum & 2 & $0.8 \%$ \\
\hline Nanton & 2 & $0.8 \%$ \\
\hline Didsbury & 2 & $0.8 \%$ \\
\hline Pines Creek & 2 & $0.8 \%$ \\
\hline Stavely & 1 & $0.4 \%$ \\
\hline Nelson, BC & 1 & $0.4 \%$ \\
\hline Coaldale & 1 & $0.4 \%$ \\
\hline Fernie, BC & 1 & $0.4 \%$ \\
\hline Bellevue & 1 & $0.4 \%$ \\
\hline Picture Butte & 1 & $0.4 \%$ \\
\hline Kempville, ONT & $0.4 \%$ \\
\hline Brooks & 1 & $0.4 \%$ \\
\hline Utah, USA & $2.0 \%$ \\
\hline TOTALS & 2 & \\
\hline
\end{tabular}





\begin{tabular}{|c|c|}
\hline \multicolumn{2}{|c|}{ Description of access point used by anglers designated as "13" on spread sheet } \\
\hline Angler No. & \begin{tabular}{|c|} 
Access Point \\
\end{tabular} \\
\hline 37 & parked on shoulder SW of Cottonwood bridge \\
\hline 39 & parked in campsite on Ramrodders property NE of Summerview bridge \\
\hline 45 & parked on NW shoulder of Hwy \#2 bridge \\
\hline 46 & same vehicle as angler \# 45 \\
\hline 47 & same vehicle as angler \# 45 \\
\hline 152 & parked at hydro-lines SE of Summerview bridge \\
\hline 153 & same vehicle as angler \# 152 \\
\hline 154 & same vehicle as angler \# 152 \\
\hline 155 & same vehicle as angler \# 152 \\
\hline 198 & parked in campsite on Ramrodders property NE of Summerview bridge \\
\hline 201 & parked at Leroy Oberton's property (visitors) \\
\hline 202 & same vehicle as angler \# 201 \\
\hline 203 & same vehicle as angler \# 201 \\
\hline 213 & walked from residence in Peigan First Nation Reservation \\
\hline 215 & parked on shoulder by park maintenance office \\
\hline 216 & same vehicle as angler \# 215 \\
\hline 247 & parked near rail road bridge upstream of Hwy \#2 bridge \\
\hline 248 & same vehicle as angler \# 247 \\
\hline
\end{tabular}





\begin{tabular}{|c|l|}
\hline \multicolumn{2}{|c|}{ Description of access points used by anglers } \\
\hline Number & \multicolumn{1}{|c|}{ Description } \\
\hline 1 & West Boulder Run access road gate (WBR) \\
\hline 2 & East Boulder Run access road gate (EBR) \\
\hline 3 & Cottonwood Boat Launch (CBL) \\
\hline 4 & Cottonwood Campground \\
\hline 5 & Cottonwood Day Use parking lot (CDU) \\
\hline 6 & SE shore at Summerview bridge \\
\hline 7 & NE shore at Summerview bridge \\
\hline 8 & Oldman River Park (ORP) \\
\hline 9 & Fort MacLeod \\
\hline 10 & SE shore down stream of 6th Avenue bridge in Fort MacLeod \\
\hline 11 & NE shore down stream of 6th Avenue bridge in Fort MacLeod \\
\hline 12 & NW shore at Monarch bridge \\
\hline 13 & Other \\
\hline
\end{tabular}





\begin{tabular}{|c|l|}
\hline \multicolumn{2}{|c|}{ Description of stretch of river used by anglers } \\
\hline Number & \multicolumn{1}{c|}{ Description } \\
\hline 1 & Oldman River Dam to Cottonwood bridge \\
\hline 2 & Cottonwood bridge to east boundary of Cottonwood Campground \\
\hline 3 & East boundary of Cottonwood Campground to Summerview bridge \\
\hline 4 & Summerview bridge to west boundary of Peigan First Nation Reservation \\
\hline 5 & East boundary of Peigan First Nation Reservation to Highway \#2 \\
\hline 6 & Highway \#2 to east boundary of the town of Fort MacLeod \\
\hline 7 & East boundary of the town of Fort MacLeod to Monarch bridge \\
\hline
\end{tabular}





\begin{tabular}{|l|l|}
\hline \multicolumn{2}{|c|}{ Legend for spreadsheet abbreviations } \\
\hline Title & Categories \\
\hline Rod Type & F = Fly rod \\
\hline & S = Spinning rod \\
\hline Bait & F = Fly \\
\hline & B = Bait \\
\hline & L = Lure \\
\hline Method & S = Standing on Shore \\
\hline & W = Wearing Waders \\
\hline & $B=$ Boat being used \\
\hline Harvest & $R=$ Release all fish caught \\
\hline & $E=$ Keep a couple to Eat fresh \\
\hline & $L=$ Keep Limit if caught \\
\hline Alone & $Y=$ Yes \\
\hline & $N=$ No, angling with others \\
\hline PRA Use & D = Day Use \\
\hline & $O=$ Overnight \\
\hline Gender & $M=$ Male \\
\hline & $F=$ Female \\
\hline Age Group & $Y=$ Youth, less than 16 years old \\
\hline & $A=$ Adult, 16 - 64 years old \\
\hline & $S=$ Seniors, 65 years old or older \\
\hline \# of fish caught & $M W=$ Mountain Whitefish \\
\hline & $R B=$ Rainbow Trout \\
\hline & $B R=$ Brown Trout \\
\hline & $B L=$ Bull Trout \\
\hline & $G E=$ Goldeye \\
\hline
\end{tabular}



Sheet8

\begin{tabular}{|c|c|}
\hline \multicolumn{2}{|c|}{$\begin{array}{l}\text { WATER FLOW RATE THROUGH } \\
\text { OLDMAN RIVER DAM DIVERSION TUNNELS }\end{array}$} \\
\hline Date & Flow Rate \\
\hline & (cubic metres/second) \\
\hline 12-Jul & 72.5 \\
\hline 13-Jul & 66.1 \\
\hline 14-Jul & 66.1 \\
\hline 15-Jul & 66.1 \\
\hline 16-Jul & 59.1 \\
\hline 17-Jul & 59.1 \\
\hline 18-Jul & 59.1 \\
\hline 19-Jul & 59.1 \\
\hline 20-Jul & 58.9 \\
\hline $21-J u l$ & 58.8 \\
\hline 22-Jul & 58.7 \\
\hline 23-Jul & 50.9 \\
\hline 24-Jul & 51 \\
\hline 25-Jul & 51.1 \\
\hline 26-Jul & 51.2 \\
\hline $27-J u l$ & 51.2 \\
\hline 28-Jul & 51.2 \\
\hline 29-Jul & 51.2 \\
\hline $30-J u l$ & 51.2 \\
\hline 31-Jul & 51.2 \\
\hline 1-Aug & 53.2 \\
\hline 2-Aug & 53.1 \\
\hline 3-Aug & 52.5 \\
\hline 4-Aug & 52.5 \\
\hline 5-Aug & 52.5 \\
\hline 6-Aug & 52.5 \\
\hline 7-Aug & 50.8 \\
\hline 8-Aug & 48.2 \\
\hline 9-Aug & 46.4 \\
\hline 10-Aug & 46.5 \\
\hline 11-Aug & 46.5 \\
\hline 12-Aug & 46.5 \\
\hline 13-Aug & 43.8 \\
\hline 14-Aug & 43.7 \\
\hline 15-Aug & 43.7 \\
\hline 16-Aug & 43.7 \\
\hline 17-Aug & 46.9 \\
\hline 18-Aug & 46.9 \\
\hline 19-Aug & 46.9 \\
\hline
\end{tabular}





\section{DISCUSSION}

Based on criteria developed for this report, and results noted, the reaches of the Oldman River below the spillway on the Oldman Dam are providing an excellent recreational fisher for Albertans and their visitors.

It is apparent from the data that most anglers fishing the stretch of the river within the P.R.A., also used the camping or day use facilities located there. As Cottonwood and Boulder Run are the two major facility areas along the river in the study area it is felt these are the areas most commonly used.

The catch per unit of effort ie. 357 fish/424 hours; equates to approximately 0.8 fish/hour by each angler. Data can be compared to creel surveys completed on lakes in northern Alberta where provincial parks and recreation areas play a role in the recreational fishery. The success for fishermen in the Oldman study area is far greater. 


